\title{
Association of Rs13118928 and Rs1828591 Polymorphisms in HHIP Gene with COPD Susceptibility: A Meta-Analysis of Case-Control Studies
}

Xue-mei Wei

People's Hospital of Xinjiang Uygur Autonomous Region

Xiao-hong Yang ( $\sim$ drhxywzz@163.com)

People's Hospital of Xinjiang Uygur Autonomous Region

\section{Research Article}

Keywords: chronic obstructive pneumonia disease, HHIP, single nucleotide polymorphism, meta-analysis

Posted Date: January 3rd, 2022

DOI: https://doi.org/10.21203/rs.3.rs-1150373/v1

License: () (i) This work is licensed under a Creative Commons Attribution 4.0 International License. Read Full License 


\section{Abstract}

In recent years, investigators have been striving to explore the pathogenesis of chronic obstructive pneumonia disease (COPD). Hedgehog Interacting Protein (HHIP) has been identified as a candidate susceptibility gene. Our aim is to synthesize and include all evidences to get a more comprehensive result. We searched 6 online databases- PubMed, Web of Science, Cochrane Library, Wanfang, EMBASE, CNKI. All included studies were published before October 1, 2021. We used Newcastle-Ottawa scale (NOS) to evaluate the bias of each study. Meta-analysis methods were conducted to evaluate the pooled result. A total of 14 comparative studies were included in this meta-analysis, for rs 13118928 polymorphism, significant associations were observed in 5 genetic models, (A vs. G, OR=1.18, 95Cl\%=[1.07-1.30], $P=0.0006$; $A A$ vs. GG, OR=1.56, $95 \mathrm{Cl} \%=[1.22-2.00], P=0.0004 ; A G$ vs. $G G, O R=1.28,95 C l \%=[1.05-1.55], P=0.01 ; A A+A G$ vs. $G G, O R=1.36,95 C l \%=[1.12-1.65], P=0.002 ; A A$ vs. $A G+G G, O R=1.18,95 \mathrm{Cl} \%=[1.05-1.33], P=0.006)$. as for $r s 1828591$, there were also significant associations detected in the overall population, $(A$ vs. $G, O R=1.12,95 \mathrm{Cl} \%=[1.05-1.19], P=0.0003 ; A A$ vs. $G G, O R=1.27,95 \mathrm{Cl} \%=[1.04-1.56], P=0.02 ; A G$ vs. $G G, O R=1.25,95 C l \%=[1.03-1.51], P=0.02$; $A A+A G$ vs. $G G, O R=1.26,95 C l \%=[1.04-1.53], P=0.02 ; A A$ vs. $A G+G G, O R=1.10,95 C l \%=[1.01-1.19], P=0.03)$. This meta-analysis showed that the $A$ allele in both rs13118928 and rs1828591 was turn out to be the risk allele in developing COPD. The result of Codominant genetic model, Dominant genetic model and Recessive genetic model remain the same.

\section{Introduction}

Pulmonary function is considered as a complex trait influenced by the interactions between multiple genetic and environmental factors. Chronic obstructive pulmonary disease (COPD) is a common lung function disorder which characterized by airflow limitations and persistent respiratory symptoms. The main cause of COPD is currently regarded as tobacco smoke and other inhalation of pollutants [1]. It is ranked as one of the major causes of death worldwide, and its high burden is rising over the years making COPD a major public health problem [2]. COPD affects approximately 174.5 million people all over the world, and its prevalence in developing country is much higher than that in developed countries $[3,4]$. Although COPD is such a highly prevalent chronic disease that makes huge personal and social influence, the underlying biological mechanisms of its etiology is yet an unanswered question.

The cause of COPD is very complicated, it is widely recognized as the interplay between external and internal co-driving factors. It is abundantly clear that the environmental exposures such as chemicals and air pollutions can contribute to COPD, while intrinsic factors such as genetics may also play an indispensable role [5, 6]. Linkage studies, Genome-wide association studies (GWAS) as well as other genetic approaches have identified numerous novel candidate genes related to COPD in the last several decades, providing us more insights in the understanding of pathogenesis. GWAS and meta-analyses of GWAS identified 15 common variants, hedgehog interacting protein (HHIP) is one of them [7]. The HHIP locus was first identified by Pillai et al [8].in the year of 2009. After that, researchers all over the world start to put their sights on single nucleotide polymorphisms (SNPs) in HHIP with the risk of COPD.

HHIP is a Protein Coding gene which is located on 4q31.21 in human chromosome, it encodes a member of the hedgehog-interacting protein (HHIP) family [9]. It interacts with all three Hedgehog $(\mathrm{HH})$ family members, Sonic Hedgehog Signaling Molecule (SHH), Indian Hedgehog Protein $(\mathrm{IHH})$ and Desert Hedgehog Signaling Molecule (DHH). The relationship of thefunctional protein is shown in Fig. 1. HHIP protein is a highly conserved, vertebrate-specific endogenous antagonist of HH signaling pathway [10]. While how important the SNPs in HHIP gene affect the phenotypes of COPD is not completed clear. Until now, many relevant studies have investigated the association of single nucleotide polymorphisms in HHIP with the risk of COPD, However, their conclusions were not comprehensive and contradictory with each other. Therefore, we aim to conduct meta-analysis on this issue to obtain a more comprehensive conclusion.

\section{Methods}

A systematic review of the literature was performed in accordance with the Preferred Reporting Items for Systematic Reviews and MetaAnalyses (PRISMA) [11].

\section{Literature search}

A comprehensive search of EMBASE, PubMed, Cochrane Library, Web of Science, CNKI, and Wanfang databases using a combination of the keywords including: "hedgehog interacting protein", "HHIP”, “Polymorphism”, "Variant", "Chronic obstructive pulmonary disease”, and "COPD”. All relevant studies up to 1 October 2021 were identified. Two investigators Wei X.M and Yang X.H separately reviewed each item to reduce selection bias and error. Any uncertainty during this process study was resolved through discussion between the two authors. In addition, related publications were screened though a manual bibliographic search of the included studies.

\section{Eligibility criteria}


Eligible studies had to satisfy the following criteria: (a) case-control or cohort study; (b) diagnosis confirmed through clinical evaluation and/or other complementary studies; (c) with sufficient genotype frequencies to calculate the effect size; (d) peer-reviewed articles. For studies with overlapping populations, the most recently published one was selected. Correspondingly, reviews, case reports, animal studies, conference abstracts, and editorials were excluded.

\section{Data extraction}

Two investigators (and) independently extracted data and arrived at a consensus. The data collected from each publication including first author's name, published year, country or region, ethnicity, gender, study design, sample size, genotype distribution, and Hardy-Weinberg equilibrium (HWE). Any differences of opinion between the reviewers were discussed until agreement was achieved.

\section{Assess of quality}

The quality of studies was evaluated by two independent investigators (and) based on the Newcastle-Ottawa Scale (NOS) for observational studies, in which three boards with eight items. The study quality is defined as poor (0 to 3), fair (4 to 6), and excellent (7 to 9$)$. Any dispute was settled through discussion.

\section{Meta-analysis}

The correlation of HHIP gene polymorphisms and COPD was estimated by using odds ratios (ORs) and 95\% confidence intervals (Cls). Five common genetic models were analyzed, including allelic model of $G$ vs. $A$, homozygous model of $G G$ vs. $A A$, heterozygous model of $G A$ vs. AA, dominant model of GG + GA vs. AA and recessive model of GG vs. GA + AA. The presence of heterogeneity between studies was assessed using the $\mathrm{I}^{2}$ and $\mathrm{Q}$ tests [12]. The fixed-effects model was used when $\mathrm{I}^{2}<50 \%, \mathrm{P}>0.05$. Otherwise, the random-effects model was adopted [13, 14]. According to ethnicity (Caucasian and Asian), subgroup analyses were performed. Sensitivity analyses were carried out using the leave-one-out procedure. Furthermore, we analyzed the publication bias by forest plots. Statistical analysis was performed using RevMan 5.3.

\section{Results}

\section{Literature search and selection}

The literature search obtained 217 publications. Of them, 103 duplicates were removed, and a further 86 were removed after assessing for relevance by screening titles and abstracts. After reading the remaining 28 full-text articles, 14 studies that did not satisfy the eligibility criteria were rejected. Finally, 14 articles were included in the present meta-analysis. The flowchart of literature selection process was illustrated in Fig. 2.

\section{Study characteristics}

Table 1 summarized the major characteristics of all included studies. A total of 14 studies were included in this work [15-28]. Among them, 12 studies analyzed the rs 13118928 polymorphism, and 9 studies investigated the rs 1828591 polymorphism. The publication years of the studies ranged from 2013 to 2021. There were 10 studies on Asians and 4 studies on Caucasians. Of note, the studies by Xie et al [21] and Xu et al [22], consisted three and two independent cohorts respectively. For rs13118928, 3 studies did not conform to HWE. Regarding NOS, 12 studies were deemed as excellent quality (with 7 to 8 scores), and the rest 2 studies were in fair quality (with 6 scores).

\section{Meta-analysis results}

Table 2 summarized the outcomes of the meta-analysis and subgroup analysis. The effect sizes were estimated based on the allelic, homozygous, heterozygous, dominant, and recessive models.

\section{Rs13118928 polymorphism and COPD}

Eleven published articles with 15 studies reported the association of rs13118928 polymorphism and COPD risk. Large heterogeneity was observed in five genetic models, and the random-effects model was used to analyze the data. The combined results supported statistical differences between the rs13118928 polymorphism and COPD: $A$ vs. G, OR=1.18, 95Cl\%=[1.07-1.30], P=0.0006; $A A$ vs. GG, OR=1.56, 95Cl\%= [1.22-2.00], $P=0.0004 ; A G$ vs. $G G, O R=1.28,95 C l \%=[1.05-1.55], P=0.01 ; A A+A G$ vs. $G G, O R=1.36,95 C l \%=[1.12-1.65], P=0.002 ; A A$ vs. $A G+G G$, $\mathrm{OR}=1.18,95 \mathrm{Cl} \%=[1.05-1.33], \mathrm{P}=0.006$. Forest plot of $\mathrm{A}$ vs. $\mathrm{G}$ in rs13118928 was illustrated in Fig 3.

Subgroup analysis based upon ethnicity revealed that the heterogeneity mainly originated from the Asians, in which the random-effects model was adopted. The pooled data indicated that rs13118928 polymorphism contributed to an increased risk to COPD in both Asians and Caucasians. 
Nine studies with ten cohorts examine the rs1828591 polymorphism and COPD susceptibility. Considerable between-study heterogeneity was found in homozygous, heterozygous, and dominant models, where the random-effects model was employed. The merged outcomes suggested rs1828591 polymorphism was correlated with COPD: A vs. G, OR=1.12, 95Cl\%=[1.05-1.19], P=0.0003; $A A$ vs. GG, OR=1.27, 95Cl\%=[1.04-1.56], $P=0.02$; $A G$ vs. $G G, O R=1.25,95 \mathrm{Cl} \%=[1.03-1.51], P=0.02 ; A A+A G$ vs. $G G, O R=1.26,95 C l \%=[1.04-1.53], P=0.02 ; A A$ vs. $A G+G G, O R=1.10,95 C l \%=$ [1.01-1.19], $P=0.03$. Forest plot of $A$ vs. $G$ in rs1828591 was illustrated in Fig 4.

Subgroup analysis by ethnicity revealed the heterogeneity mainly existed in the Asians, in which the random-effects model was adopted in four genetic models. The pooled data indicated that rs1828591 polymorphism was associated with an elevated susceptibility to COPD in both Caucasians but not Asians.

\section{Sensitivity analyses and publication bias}

After the removal the studies deviating from HWE, the corresponding pooled ORs and 95Cls were not significantly altered. Therefore, they were kept in the final data combination. Sensitivity analyses did not provide reverse outcomes regarding the rs 13118928 and rs 1828591 polymorphisms by removing each study at a time. Therefore, the sensitivity analysis confirmed that the results were reliable and robust. Forest plots did not show significant evidence of publication bias of the included studies. Labbe graph of sensitivity analyses and Funnel plot of publication bias are displayed in Fig 5 and Fig 6.

\section{Discussion}

To date, what causes the occurrence and development of COPD remains somewhat enigmatic. However, it is hard to understand why never smokers could develop COPD while some smokers never suffer from COPD. The only possible explanation is that genetic factors play an indispensable role. Most recently, Single nucleotide polymorphisms was found to be associated with lung function by using powerful genomewide association studies [29]. As intrinsic factors, polymorphisms in HHIP have drawn considerable attention over the past decade years by different researchers around the world.

GWAS have made a great contribution in screening out candidate susceptibility variants, However, it is challenging to find out functional variants. Since HHIP has been identified, numerous researchers have paid attention on its functional study, HHIP implement its function by inhibit the Hedgehog $(\mathrm{HH})$ signaling pathway which is involved in various biological processes. The HH signaling pathway plays essential role in the development of lung injury when encounter risk factors. All these evidences entitled HHIP as a pivotal role in COPD development [30]. The mRNA and protein levels of HHIP is found to be reduced In Zhou et al.'s studies, indicating HHIP is a pivotal functional variant underlying COPD pathogenesis [31]. Other evidence demonstrated that phenotypes such as different types of emphysema and distinct severity of emphysema were also were also associated with HHIP single nucleotide polymorphisms, and HHIP gene affects emphysema measurements phenotype more than airway phenotypes [32,33]. These findings indicated that the genetic variation of the HHIP region leads to the alteration of HHIP protein expression, subsequently results in different risk of pulmonary phenotypes. Apart from lung function phenotype, HHIP is also associated with infant and adult height [34]. An in vivo and in vitro study conducted by Li et.al [35] suggests that HHIP represses aerobic glycolysis and the hyperplasia of airway smooth muscle cells.

It is clear SNP loci in the genome may influence the phenotype and gene function by changing the encoded amino acid or only by appearing in the noncoding regions [36]. However, not all the SNP loci in the genome confer risk to the development of COPD, and the extent of the risk effect in these loci are distinct with each other. According to this meta-analysis, the two most studied loci of HHIP are rs13118928 and rs1828591. Of them, 9 included studies were written in English while 5 included studies were written in Chinese. For rs13118928, 11 studies including 15 cohorts were calculated. Despite that most of the included studies confirmed no statistical significance between rs13118928 (HHIP) and COPD, However, the pooled outcome showed a significant statistical result. According to Korytina et al.'s study [37], there is no significant statistical association between rs13118928 (HHIP) and COPD in Tatars population in Russia, while another study conducted in a Polish population by Zhou et al. [31] revealed that rs13118928 account for severe COPD in smokers. The total results demonstrated that A allele was turn out to be the risk factor compared with $\mathrm{G}$ allele when in the allelic genetic model. The statistical results remain the same when we calculated using codominant genetic model, dominant genetic model, and recessive genetic model. To minimize heterogeneity, subgroup was divided into Asian and Caucasian, the results were broadly consistent. For rs 1828591,9 studies including 10 cohorts were estimated. The results were mostly in consistent with rs13118928, the A allele in COPD patients was significantly higher than that of control groups.

Apart from rs13118928 and rs1828591, there were also some other SNP loci, due to the limited number of studies and lack of adequate necessary information, the meta-analysis didn't include them, However, their importance should not be ignored. Mustofa et. al's study in 2021 revealed that there was lack of association between rs10519717 in the HHIP and COPD, another study by Xie et.al in 2015 identified two new regions rs11100865 and rs7654947 which showed a significant risk for develop COPD. 
To the best of our knowledge, this is the most comprehensive and integrated meta-analysis according to our literature search. Although we have included all the English and Chinese published articles all over the world and have done sub-group analysis to overcome the study heterogeneity and publish bias, several drawbacks of this work should not be over look. First, COPD is a disease caused by multiple genes and numerous loci polymorphisms, we only concentrate on rs11100865 and rs7654947 in HHIP, SNP loci in other gene should not be ignored. Second, we only included published articles written in English and Chinese, literatures published in other language were not considered in this meta-analysis, that may lead to selection bias. Third, although most of control groups in included studies were in consistent with HWE, a few of them did not have adequate information or were not in accord with HWE, that may distort the results. Finally, despite we have conducted sub-group analysis of the included studies, we couldn't eliminate all the heterogeneity, such as age, standard for testing methods, severity of disease, etc., could also biased the meta-analysis results.

\section{Conclusion}

In conclusion, our work has identified two most common loci rs13118928(A/G) and rs1828591( $A / G)$ in HHIP gene which confer increased risk for COPD in five genetic models, the results of sub-group analysis divided by ethnicity remain unchanged. The mechanism underlying these phenomenon needs further investigation.

\section{Abbreviations}

\begin{tabular}{|ll|}
\hline COPD & chronic obstructive pneumonia disease \\
\hline SNP & single nucleotide polymorphism \\
\hline HHIP & Hedgehog Interacting Protein \\
NOS & Newcastle-Ottawa scale \\
\hline OR & odds ratio \\
CI & confidence interval \\
\hline HWE & hardy-weinberg equilibrium \\
\hline GWAS & Genome-wide association studies \\
\hline
\end{tabular}

\section{Declarations}

\section{Author Contributions}

Yang X. H conceived of the original idea and did the first draft of this paper. Yang X. $\mathrm{H}$ and Wei X. M did the data analyses together. Yang X. $\mathrm{H}$ revised the final work and was responsible for the whole work. The two authors have read and agreed to publish this paper.

\section{Competing interests}

No conflict of interest to declare.

\section{Compliance with Ethical Standards}

We obtain all the data from previous-published literatures in public databases, no human and animals were involved in this work, therefore, there is no need for ethical approval and patient consent.

\section{Funding}

None

\section{References}

1. Lareau, S. C., Fahy, B., Meek, P. \& Wang, A. Chronic Obstructive Pulmonary Disease (COPD). Am. J. Respir. Crit. Care Med. 199, P1-p2, (2019).

2. López-Campos, J. L., Tan, W. \& Soriano, J. B. Global burden of COPD. Respirology. 21, 14-23 (2016).

3. Wouters, E. F. M., Breyer, M. K., Breyer-Kohansal, R. \& Hartl, S. COPD Diagnosis: Time for Disruption. Journal of clinical medicine. 10, (2021).

4. Zhu, B., Wang, Y., Ming, J., Chen, W. \& Zhang, L. Disease burden of COPD in China: a systematic review. Int J Chron Obstruct Pulmon Dis. Pulmon. Dis. 13, 1353-1364, (2018). 
5. Seifart, C. \& Plagens, A. Genetics of chronic obstructive pulmonary disease. Int J Chron Obstruct Pulmon Dis. Dis. 2, 541-550 (2007).

6. Nakamura, H. Genetics of COPD. Allergology international: official journal of the Japanese Society of Allergology 60, 253-258, (2011).

7. Ranjan, A., Singh, A., Walia, G. K., Sachdeva, M. P. \& Gupta, V. Genetic underpinnings of lung function and COPD. Journal of genetics. 98 (2019).

8. Pillai, S. G. et al. A genome-wide association study in chronic obstructive pulmonary disease (COPD): identification of two major susceptibility loci. PLoS Genet. 5, e1000421, (2009).

9. Kim, W. J. \& Lee, S. D. Candidate genes for COPD: current evidence and research. Int. J. Chron. Obstruct. Pulmon. Dis. 10, 2249-2255, (2015).

10. Cohen, M. M., Jr. Hedgehog signaling update. Am. J. Med. Genet. A 152a, 1875-1914, (2010).

11. Liberati, A. et al. The PRISMA statement for reporting systematic reviews and meta-analyses of studies that evaluate health care interventions: explanation and elaboration. Journal of clinical epidemiology. 62, e1-34, (2009).

12. Higgins, J. P., Thompson, S. G., Deeks, J. J. \& Altman, D. G. Measuring inconsistency in meta-analyses. BMJ. 327, 557-560, (2003).

13. DerSimonian, R. \& Laird, N. Meta-analysis in clinical trials. Control. Clin. Trials 7, 177-188, (1986).

14. Mantel, N. \& Haenszel, W. Statistical aspects of the analysis of data from retrospective studies of disease. Journal of the National Cancer Institute. 22, 719-748 (1959).

15. Mustofa, S. et al. The snp rs13118928, rs1828591 and rs10519717 in the hhip gene are not associated on copd susceptibility in male javanese smokers. Indian Journal of Forensic Medicine and Toxicology 15, 2665-2673, (2021).

16. Ortega-Martínez, A. et al. The SNP rs13147758 in the HHIP Gene Is Associated With COPD Susceptibility, Serum, and Sputum Protein Levels in Smokers. Frontiers in Genetics 11, (2020).

17. Ortega-Martínez, A. et al. Participation of HHIP gene variants in COPD susceptibility, lung function, and serum and sputum protein levels in women exposed to biomass-burning smoke. Diagnostics 10, (2020).

18. Ortega-Martínez, A. et al. The SNP rs13147758 in the HHIP Gene Is Associated With COPD Susceptibility, Serum, and Sputum Protein Levels in Smokers. Front Genet 11, 882, (2020).

19. Van Durme, Y. M. et al. Hedgehog-interacting protein is a COPD susceptibility gene: the Rotterdam Study. Eur. Respir. J. 36, 89-95, (2010).

20. Wang, B. et al. Association of HHIP polymorphisms with COPD and COPD-related phenotypes in a Chinese Han population. Gene 531, 101105, (2013).

21. Xie, J. et al. Gene susceptibility identification in a longitudinal study confirms new loci in the development of chronic obstructive pulmonary disease and influences lung function decline. Respir. Res. 16, 49, (2015).

22. Xu, G. et al. Comparison of the role of HHIP SNPs in susceptibility to chronic obstructive pulmonary disease between Chinese Han and Mongolian populations. Gene 637, 50-56, (2017).

23. Zhang, Z. et al. Genetic Variants in the Hedgehog Interacting Protein Gene Are Associated with the FEV1/FVC Ratio in Southern Han Chinese Subjects with Chronic Obstructive Pulmonary Disease. BioMed research internationa/ 2017, 2756726, (2017).

24. Cheng F, et al. Relationship between HHIP Gene Polymorphism and Chronic Obstructive Pulmonary Disease Susceptibility in Kazakh Population in Xinjiang, China. Chinese General Practice. 20, 2378-2382, (2017).

25. Ma C, et al. Study on the correlation between HHIP gene Rs13118928, Rs13141461 and susceptibility to chronic obstructive pulmonary disease in Xinjiang Mongolian. Guangzhou medicine. 49, 1-5, (2018).

26. Ren X, et al. Correlation between single nucleotide polymorphism of HHIP gene and susceptibility to gong obstructive pulmonary disease in Xinjiang Uygur population. Shandong medicine.56, 12-14, (2016).

27. Ren X, Guan J, Zhang Z, Cheng F, Ma C. Correlation between HHIP gene RS1828591, RS12504628 and chronic obstructive pulmonary disease in Xinjiang Uygur. Journal of Practical Medicine. 33, 692-695, (2017).

28. Wang W, et al. Analysis of the HHIP Gene Sequence Map Characteristics of Patients with Refractory COPD Correlation of Points and Susceptibility. Mod Diagn Treat. 21, 2865-2867, (2020).

29. Liao, S. Y., Lin, X. \& Christiani, D. C. Genome-wide association and network analysis of lung function in the Framingham Heart Study. Genet. Epidemiol. 38, 572-578, (2014).

30. Chuang, P. T., Kawcak, T. \& McMahon, A. P. Feedback control of mammalian Hedgehog signaling by the Hedgehog-binding protein, Hip1, modulates Fgf signaling during branching morphogenesis of the lung. Genes \& development 17, 342-347, (2003).

31. Zhou, X. et al. Identification of a chronic obstructive pulmonary disease genetic determinant that regulates HHIP. Hum Mol Genet 21, 13251335, (2012).

32. Cho, M. H. et al. A Genome-Wide Association Study of Emphysema and Airway Quantitative Imaging Phenotypes. Am. J. Respir. Crit. Care Med. 192, 559-569, (2015).

Page 6/16 
33. Castaldi, P. J. et al. Cluster analysis in the COPD Gene study identifies subtypes of smokers with distinct patterns of airway disease and emphysema. Thorax. 69, 415-422, (2014).

34. van der Valk, R. J. et al. A novel common variant in DCST2 is associated with length in early life and height in adulthood. Hum Mol Genet. 24, 1155-1168, (2015).

35. Li, Y. et al. Hedgehog interacting protein (HHIP) represses airway remodeling and metabolic reprogramming in COPD-derived airway smooth muscle cells. Scientific reports. 11, 9074, (2021).

36. Shastry, B. S. SNPs: impact on gene function and phenotype. Methods Mol Biol. 578, 3-22, (2009).

37. Korytina, G. F., Akhmadishina, L. Z., Viktorova, E. V., Kochetova, O. V. \& Viktorova, T. V. IREB2, CHRNA5, CHRNA3, FAM13A \& hedgehog interacting protein genes polymorphisms \& risk of chronic obstructive pulmonary disease in Tatar population from Russia. Indian J. Med. Res. 144, 865-876, (2016).

\section{Tables}

Table 1 Characteristics of included studies 


\begin{tabular}{|c|c|c|c|c|c|c|c|c|c|c|c|c|c|}
\hline \multirow[t]{2}{*}{ Author/year } & \multirow[t]{2}{*}{ Nation } & \multirow[t]{2}{*}{ Ethnicity } & \multirow[t]{2}{*}{ Gender } & \multirow[t]{2}{*}{ Design } & \multirow{2}{*}{$\begin{array}{l}\text { Sample } \\
\text { size }\end{array}$} & \multicolumn{3}{|l|}{ Case } & \multicolumn{3}{|c|}{ Control } & \multirow{2}{*}{$\begin{array}{l}\text { HWE } \\
(\mathrm{P}- \\
\text { value })\end{array}$} & \multirow[t]{2}{*}{ NOS } \\
\hline & & & & & & $A A$ & $A G$ & GG & $A A$ & $A G$ & GG & & \\
\hline \multicolumn{14}{|l|}{ Rs13118928 } \\
\hline $\begin{array}{l}\text { Cheng F, } \\
2017\end{array}$ & China & Asian & Both & $\begin{array}{l}\text { Case- } \\
\text { control }\end{array}$ & $213 / 350$ & 58 & 106 & 49 & 89 & 168 & 93 & 0.46 & 7 \\
\hline $\begin{array}{l}\text { Korytina GF, } \\
2016\end{array}$ & Russia & European & Both & $\begin{array}{l}\text { Case- } \\
\text { control }\end{array}$ & $511 / 508$ & 245 & 215 & 51 & 240 & 198 & 70 & 0.01 & 8 \\
\hline Ma C, 2018 & China & Asian & Both & $\begin{array}{l}\text { Case- } \\
\text { control }\end{array}$ & $243 / 239$ & 110 & 100 & 33 & 60 & 115 & 64 & 0.57 & 7 \\
\hline $\begin{array}{l}\text { Mustofa S, } \\
2021\end{array}$ & Indonesia & Asian & NA & $\begin{array}{l}\text { Case- } \\
\text { control }\end{array}$ & $55 / 55$ & 29 & 25 & 1 & 26 & 29 & 0 & 0.01 & 6 \\
\hline $\begin{array}{l}\text { Ortega- } \\
\text { Martínez A, } \\
2020 \text { (I) }\end{array}$ & Mexico & European & Female & $\begin{array}{l}\text { Case- } \\
\text { control }\end{array}$ & $186 / 557$ & 88 & 86 & 12 & 258 & 233 & 66 & 0.24 & 7 \\
\hline Ren X, 2016 & China & Asian & Both & $\begin{array}{l}\text { Case- } \\
\text { control }\end{array}$ & $233 / 292$ & 67 & 103 & 63 & 94 & 138 & 60 & 0.48 & 7 \\
\hline $\begin{array}{l}\text { Van Durme } \\
\text { YM, } 2013\end{array}$ & Netherlands & European & Both & Cohort & $742 / 4976$ & 294 & 359 & 89 & 1805 & 2339 & 832 & 0.12 & 8 \\
\hline $\begin{array}{l}\text { Wang B, } \\
2013\end{array}$ & China & Asian & Both & $\begin{array}{l}\text { Case- } \\
\text { control }\end{array}$ & $680 / 687$ & 354 & 271 & 55 & 339 & 288 & 60 & 0.92 & 7 \\
\hline $\begin{array}{l}\text { Wang W, } \\
2020\end{array}$ & China & Asian & Both & $\begin{array}{l}\text { Case- } \\
\text { control }\end{array}$ & $100 / 100$ & 49 & 40 & 11 & 20 & 55 & 25 & 0.31 & 6 \\
\hline $\begin{array}{l}\text { Xie J, } 2015 \\
\text { (a) }\end{array}$ & China & Asian & Both & Cohort & $541 / 560$ & 289 & 212 & 40 & 282 & 222 & 56 & 0.22 & 8 \\
\hline $\begin{array}{l}\text { Xie J, } 2015 \\
\text { (b) }\end{array}$ & China & Asian & Both & Cohort & $409 / 611$ & 202 & 155 & 52 & 269 & 290 & 52 & 0.04 & 8 \\
\hline $\begin{array}{l}\text { Xie J, } 2015 \\
\text { (c) }\end{array}$ & China & Asian & Both & Cohort & $374 / 377$ & 182 & 167 & 25 & 180 & 162 & 35 & 0.87 & 8 \\
\hline $\begin{array}{l}\text { Xu G, } 2017 \\
\text { (a) }\end{array}$ & China & Asian & Both & $\begin{array}{l}\text { Case- } \\
\text { control }\end{array}$ & $350 / 350$ & 176 & 142 & 32 & 153 & 147 & 50 & 0.14 & 7 \\
\hline $\begin{array}{l}\text { Xu G, } 2017 \\
\text { (b) }\end{array}$ & China & Asian & Both & $\begin{array}{l}\text { Case- } \\
\text { control }\end{array}$ & $350 / 350$ & 112 & 203 & 35 & 119 & 168 & 63 & 0.79 & 7 \\
\hline $\begin{array}{l}\text { Zhang Z, } \\
2017\end{array}$ & China & Asian & Both & $\begin{array}{l}\text { Case- } \\
\text { control }\end{array}$ & 987/999 & 581 & 358 & 48 & 559 & 374 & 66 & 0.75 & 8 \\
\hline \multicolumn{14}{|l|}{ Rs1828591 } \\
\hline $\begin{array}{l}\text { Cheng F, } \\
2017\end{array}$ & China & Asian & Both & $\begin{array}{l}\text { Case- } \\
\text { control }\end{array}$ & $214 / 350$ & 60 & 106 & 48 & 89 & 167 & 94 & 0.40 & 7 \\
\hline $\begin{array}{l}\text { Mustofa S, } \\
2021\end{array}$ & Indonesia & Asian & NA & $\begin{array}{l}\text { Case- } \\
\text { control }\end{array}$ & $55 / 55$ & 29 & 24 & 2 & 21 & 29 & 5 & 0.26 & 6 \\
\hline $\begin{array}{l}\text { Ortega- } \\
\text { Martínez A, } \\
2020 \text { (I) }\end{array}$ & Mexico & European & Female & $\begin{array}{l}\text { Case- } \\
\text { control }\end{array}$ & $186 / 557$ & 90 & 77 & 19 & 257 & 232 & 68 & 0.17 & 7 \\
\hline $\begin{array}{l}\text { Ortega- } \\
\text { Martínez A, } \\
2020 \text { (II) }\end{array}$ & Mexico & European & Both & $\begin{array}{l}\text { Case- } \\
\text { control }\end{array}$ & $222 / 333$ & 87 & 100 & 35 & 143 & 141 & 49 & 0.15 & 7 \\
\hline Ren X, 2017 & China & Asian & Both & $\begin{array}{l}\text { Case- } \\
\text { control }\end{array}$ & $233 / 292$ & 67 & 103 & 63 & 96 & 136 & 60 & 0.36 & 7 \\
\hline
\end{tabular}




\begin{tabular}{|c|c|c|c|c|c|c|c|c|c|c|c|c|c|}
\hline $\begin{array}{l}\text { Van Durme } \\
\text { YM, } 2013\end{array}$ & Netherlands & European & Both & Cohort & $742 / 4976$ & 293 & 360 & 89 & 1799 & 2343 & 834 & 0.13 & 8 \\
\hline $\begin{array}{l}\text { Wang B, } \\
2013\end{array}$ & China & Asian & Both & $\begin{array}{l}\text { Case- } \\
\text { control }\end{array}$ & $678 / 685$ & 354 & 270 & 54 & 339 & 288 & 58 & 0.78 & 7 \\
\hline $\begin{array}{l}\text { Xu G, } 2017 \\
\text { (a) }\end{array}$ & China & Asian & Both & $\begin{array}{l}\text { Case- } \\
\text { control }\end{array}$ & $350 / 350$ & 176 & 144 & 30 & 153 & 146 & 51 & 0.10 & 7 \\
\hline $\begin{array}{l}\text { Xu G, } 2017 \\
\text { (b) }\end{array}$ & China & Asian & Both & $\begin{array}{l}\text { Case- } \\
\text { control }\end{array}$ & $350 / 350$ & 112 & 203 & 35 & 119 & 170 & 61 & 0.99 & 7 \\
\hline $\begin{array}{l}\text { Zhang Z, } \\
2017\end{array}$ & China & Asian & Both & $\begin{array}{l}\text { Case- } \\
\text { control }\end{array}$ & $985 / 996$ & 581 & 356 & 48 & 559 & 374 & 63 & 0.97 & 8 \\
\hline
\end{tabular}

HWE, Hardy-Weinberg Equilibrium; NOS, Newcastle-Ottawa Scale

Table 2 Association between HHIP gene polymorphism and chronic obstructive pulmonary disease 


\begin{tabular}{|c|c|c|c|c|c|c|c|}
\hline \multirow[t]{2}{*}{ Genetic model } & \multicolumn{3}{|c|}{ Effect size } & \multirow[t]{2}{*}{ No. of cohorts } & \multirow[t]{2}{*}{ Effect model } & \multicolumn{2}{|c|}{ Heterogeneity } \\
\hline & OR & $95 \% \mathrm{Cl}$ & P-value & & & $\mathrm{I}^{2}(\%)$ & P-value \\
\hline \multicolumn{8}{|c|}{ Rs13118928(AVG) } \\
\hline \multicolumn{8}{|l|}{ Total } \\
\hline A vs. G & 1.18 & $1.07-1.30$ & 0.0006 & 15 & $\mathrm{R}$ & 67 & 0.0001 \\
\hline AA vs. GG & 1.56 & $1.22-2.00$ & 0.0004 & 15 & $\mathrm{R}$ & 75 & $\triangle 0.0001$ \\
\hline$A G v s . G G$ & 1.28 & $1.05-1.55$ & 0.01 & 15 & $\mathrm{R}$ & 60 & 0.001 \\
\hline$A A+A G$ vs. GG & 1.36 & $1.12-1.65$ & 0.002 & 15 & $\mathrm{R}$ & 64 & 0.0003 \\
\hline$A A v s . A G+G G$ & 1.18 & $1.05-1.33$ & 0.006 & 15 & $\mathrm{R}$ & 62 & 0.0008 \\
\hline \multicolumn{8}{|l|}{ Asian } \\
\hline A vs. G & 1.20 & $1.05-1.36$ & 0.005 & 12 & $\mathrm{R}$ & 73 & $\triangle 0.0001$ \\
\hline AA vs. GG & 1.45 & $1.08-1.95$ & 0.01 & 12 & $\mathrm{R}$ & 74 & $\bowtie 0.0001$ \\
\hline AG vs. GG & 1.21 & $0.94-1.54$ & 0.13 & 12 & $\mathrm{R}$ & 64 & 0.001 \\
\hline$A A+A G v s . G G$ & 1.32 & $1.02-1.70$ & 0.03 & 12 & $\mathrm{R}$ & 70 & 0.0001 \\
\hline$A A v s . A G+G G$ & 1.23 & $1.05-1.44$ & 0.01 & 12 & $\mathrm{R}$ & 69 & 0.0002 \\
\hline \multicolumn{8}{|l|}{ Caucasian } \\
\hline A vs. G & 1.16 & $1.06-1.27$ & 0.0009 & 3 & $\mathrm{~F}$ & 0 & 0.83 \\
\hline AA vs. GG & 1.52 & $1.25-1.87$ & $\varangle 0.0001$ & 3 & $\mathrm{~F}$ & 0 & 0.76 \\
\hline AG vs. GG & 1.50 & $1.23-1.83$ & $凶 0.0001$ & 3 & $\mathrm{~F}$ & 0 & 0.63 \\
\hline$A A+A G v s . G G$ & 1.51 & $1.24-1.82$ & $\varangle 0.0001$ & 3 & $\mathrm{~F}$ & 0 & 0.70 \\
\hline$A A v s . A G+G G$ & 1.10 & $0.98-1.25$ & 0.12 & 3 & $\mathrm{~F}$ & 0 & 0.69 \\
\hline \multicolumn{8}{|l|}{ Rs1828591 (AVG) } \\
\hline \multicolumn{8}{|l|}{ Total } \\
\hline A vs. G & 1.12 & $1.05-1.19$ & 0.0003 & 10 & $\mathrm{~F}$ & 39 & 0.10 \\
\hline AA vs. GG & 1.27 & $1.04-1.56$ & 0.02 & 10 & $\mathrm{R}$ & 48 & 0.05 \\
\hline$A G v s . G G$ & 1.25 & $1.03-1.51$ & 0.02 & 10 & $\mathrm{R}$ & 42 & 0.08 \\
\hline$A A+A G v s . G G$ & 1.26 & $1.04-1.53$ & 0.02 & 10 & $\mathrm{R}$ & 52 & 0.03 \\
\hline$A A v s . A G+G G$ & 1.10 & $1.01-1.19$ & 0.03 & 10 & $\mathrm{~F}$ & 0 & 0.44 \\
\hline \multicolumn{8}{|l|}{ Asian } \\
\hline A vs. G & 1.11 & $0.99-1.24$ & 0.06 & 7 & $\mathrm{R}$ & 45 & 0.09 \\
\hline$A A$ vs. GG & 1.30 & $0.98-1.72$ & 0.07 & 7 & $\mathrm{R}$ & 54 & 0.07 \\
\hline$A G v s . G G$ & 1.25 & $0.98-1.59$ & 0.08 & 7 & $\mathrm{R}$ & 48 & 0.06 \\
\hline$A A+A G v s . G G$ & 1.28 & $0.97-1.70$ & 0.08 & 7 & $\mathrm{R}$ & 60 & 0.02 \\
\hline$A A v s . A G+G G$ & 1.10 & $0.99-1.22$ & 0.07 & 7 & $\mathrm{~F}$ & 9 & 0.36 \\
\hline \multicolumn{8}{|l|}{ Caucasian } \\
\hline A vs. G & 1.13 & $1.03-1.24$ & 0.01 & 3 & $\mathrm{~F}$ & 49 & 0.14 \\
\hline AA vs. GG & 1.24 & $0.87-1.77$ & 0.23 & 3 & $\mathrm{R}$ & 52 & 0.13 \\
\hline AG vs. GG & 1.33 & $1.08-1.63$ & 0.007 & 3 & $\mathrm{~F}$ & 0 & 0.40 \\
\hline$A A+A G v s . G G$ & 1.34 & $1.10-1.62$ & 0.003 & 3 & $\mathrm{~F}$ & 37 & 0.20 \\
\hline$A A v s . A G+G G$ & 1.09 & $0.96-1.25$ & 0.18 & 3 & $\mathrm{~F}$ & 15 & 0.31 \\
\hline
\end{tabular}


$\mathrm{OR}$, odds ratio; $\mathrm{Cl}$, confidence interval; $\mathrm{F}$, fix-effect model; $\mathrm{R}$, random-effect model

\section{Figures}

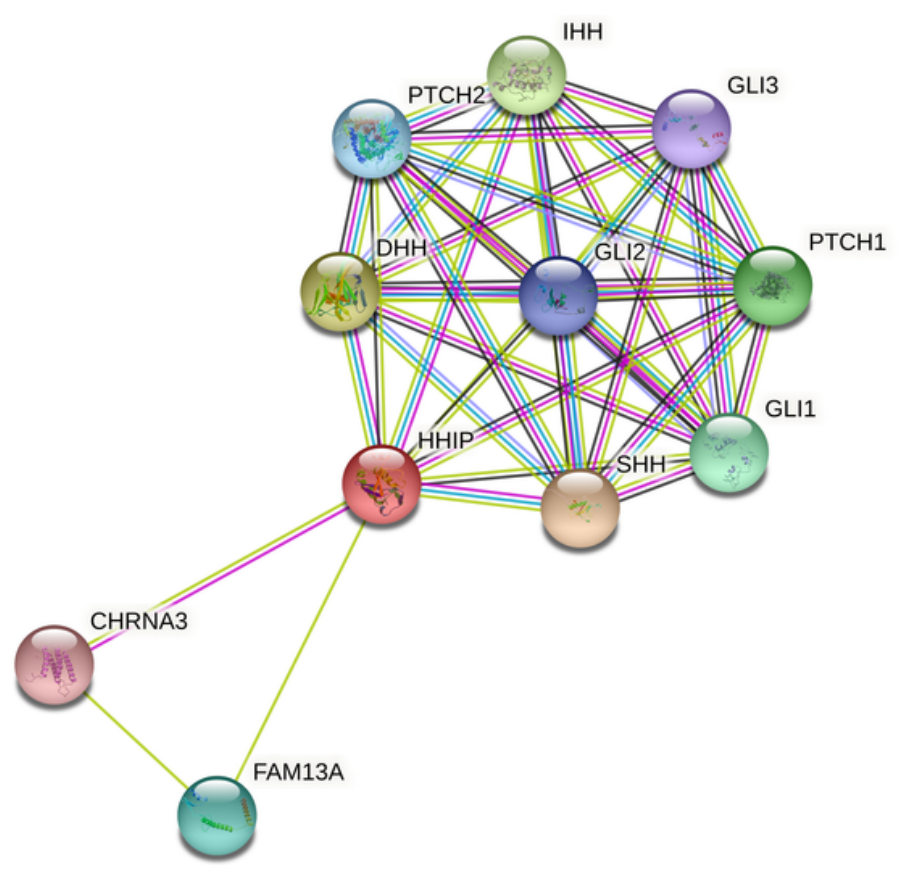

\section{Figure 1}

Relationship network of HHIP and its closest functional partners. We obtain these data from public online database of Search Tool for the Retrieval of Interacting Genes (STRING) (http://string-db.org/) 


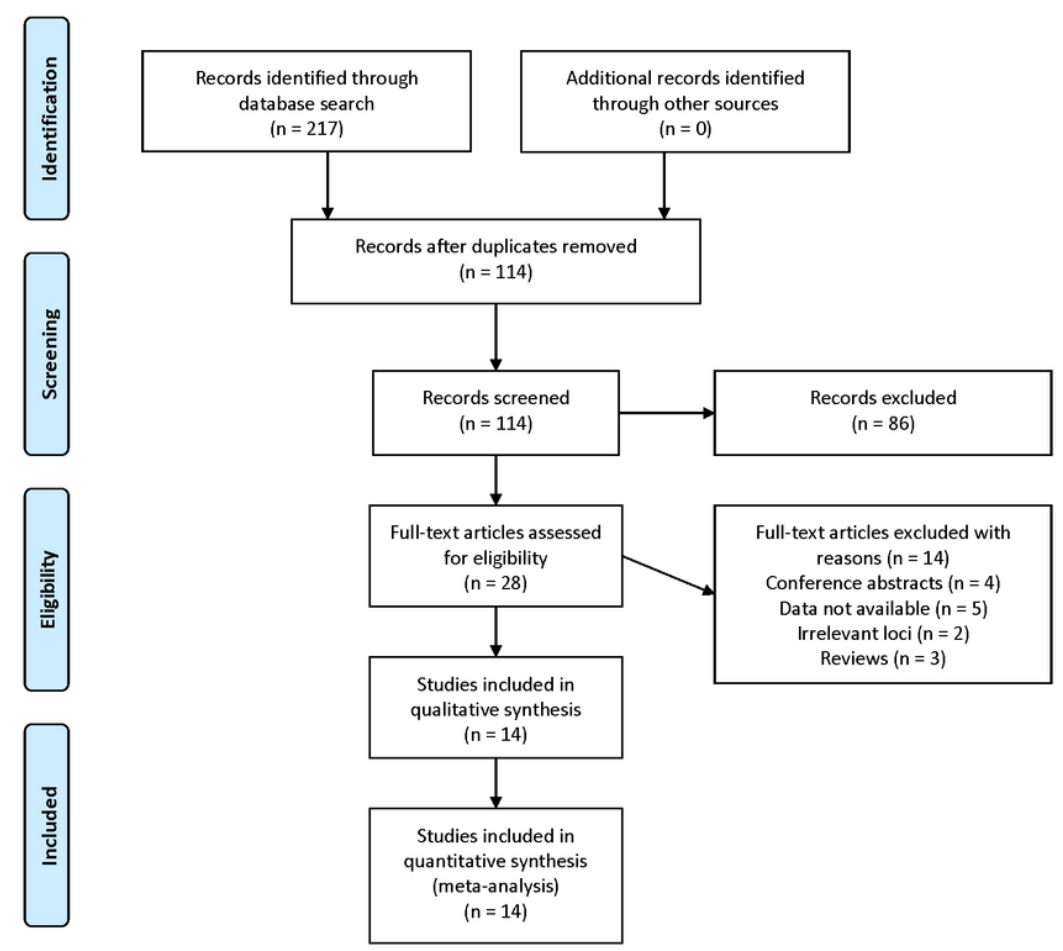

Figure 2

Flow diagram of literature search and screen 


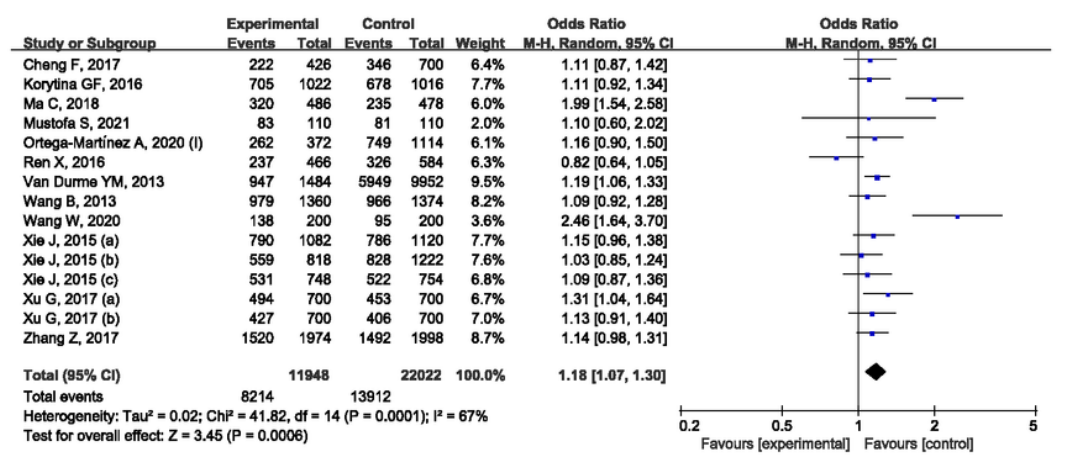

Figure 3

Forest plot of Allelic model (A vs. G) in HHIP (rs13118928) and risk of COPD. 


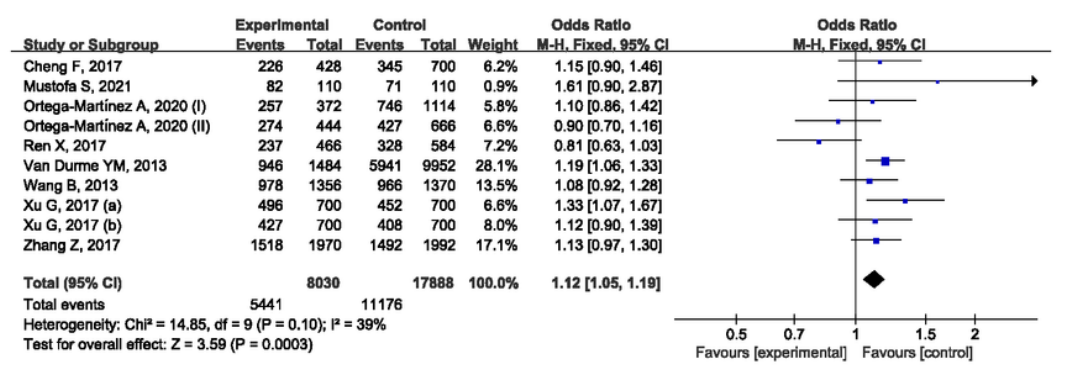

Figure 4

Forest plot of Allelic model (A vs. G) in HHIP (rs1828591) and risk of COPD. 
Rs13118928

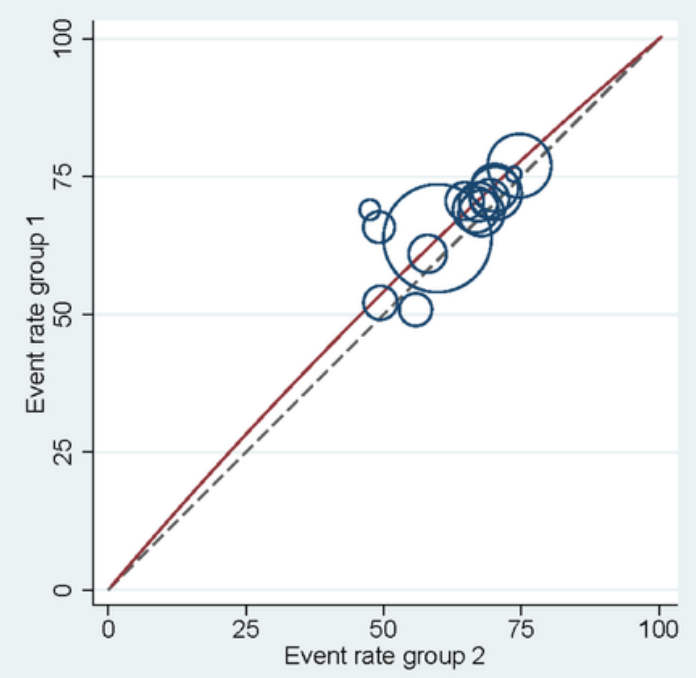

Rs1828591

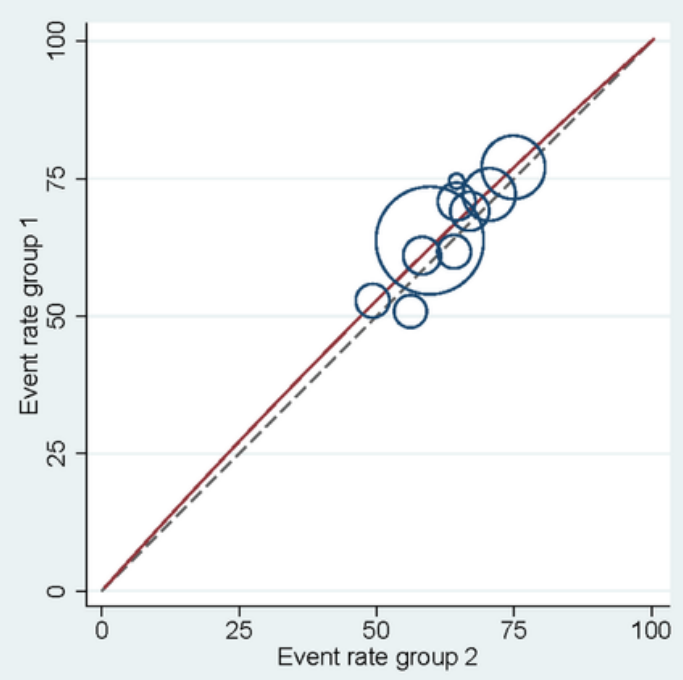

Figure 5

Sensitivity analyses of rs13118928 and rs1828591 illustrated by Labbe graph. 


\section{Rs13118928}

\section{Rs1828591}
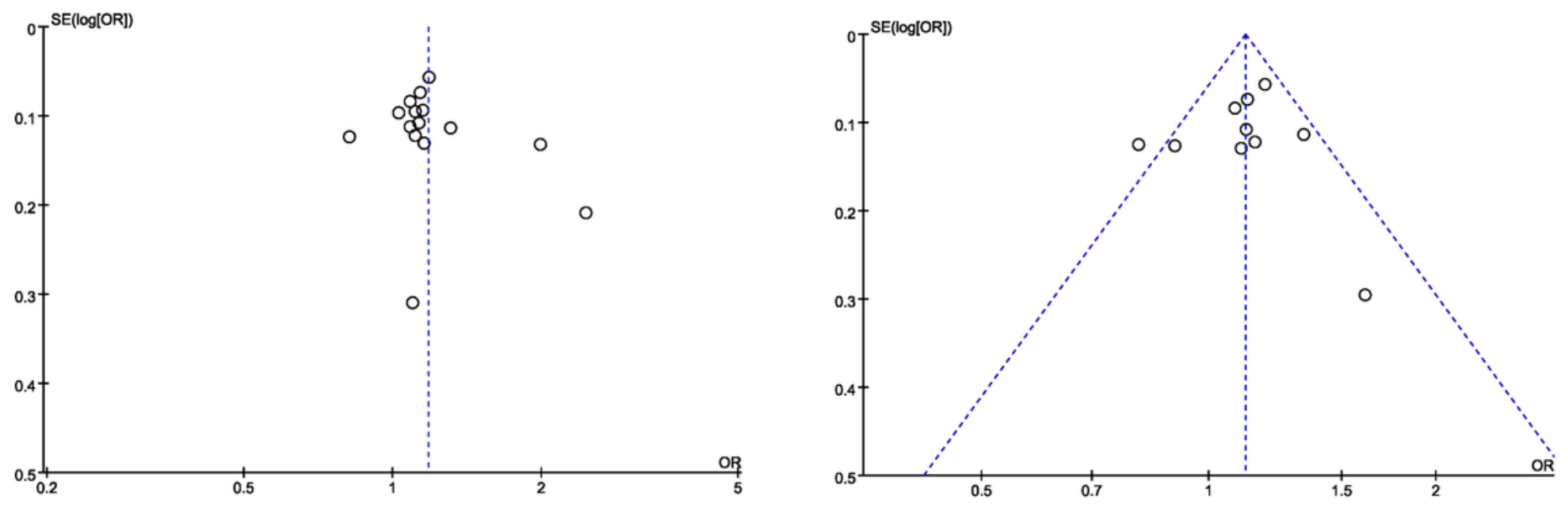

\section{Figure 6}

Publication bias of rs13118928 and rs1828591 illustrated by Funnel plot.

\section{Supplementary Files}

This is a list of supplementary files associated with this preprint. Click to download.

- PRISMA2020checklist.docx 